\title{
The Effect of Endurance Exercises Method to Increase VO2Max Wrestling Athlete in Indonesia
}

\author{
Rubianto Hadi \\ Department of Sports Coaching \\ Education, \\ Faculty of Sports Sciences, \\ Universitas Negeri Semarang \\ Semarang, Indonesia \\ rubianto_hd63@gmail.com
}

\author{
Hari Setijono \\ Department of Sports Coaching \\ Education, \\ Faculty of Sports Sciences, \\ Universitas Negeri Surabaya \\ Surabaya, Indonesia \\ harisetijono@yahoo.co.ic
}

\author{
Soegiyanto \\ Department of Sports Sciences, \\ Faculty of Sports Sciences \\ Universitas Negeri Semarang, \\ Semarang, Indonesia \\ soegiyanto.ks@mail.unnes.ac.id
}

\author{
Setya Rahayu \\ Department of Sports Sciences, \\ Faculty of Sports Sciences, \\ Universitas Negeri Semarang, \\ Semarang, Indonesia \\ setyarahayu@mail.unnes.ac.id
}

\begin{abstract}
The results showed that VO2 Max as a whole result of pretest result $46,95 \%$, result of test of Cycle I increased to equal to $49,43 \%$, and result of Cycle II test become more good again reach $50,21 \%$. The conclusion of this study is that the training interval method can to increase the VO2 Max Atlet Wrestling Program Indonesia Golden Games XXVII Myanmar 2013 so that its durability increases. The study's recommendation is to improve endurance athletes using interval training methods.
\end{abstract}

Keywords_-VO2Max, endurance, interval training

\section{INTRODUCTION}

Sports wrestling is rarely heard echo in Indonesia, but the real fact is not so. Although not as popular as football, badminton or tennis, but this type of hard sport also still exist in Indonesia. Since the entry of new types of sports to Indonesia such as sumo, wushu, or other similar sports, wrestling is seeming abandoned. Though the history until the development of this sport in Indonesia through several stages is quite difficult, including its existence is almost completely eliminated since Japan came to bring sports like Judo and Kempo.

Until finally wrestling again popularized in 1959 with the match in Bandung. This physical exercise was also contested in the grand event of ASIAN GAMES IV in 1962 so that Indonesia should briefly establish a special wrestling association to recruit athletes and provide education / coaching for prospective athletes.

The association is called the All Amateur Wrestling Union of Indonesia or abbreviated as PGSI. The association was founded on February 7, 1960 and has hosted this branch sport until now. PGSI is under KONI and regularly conducts athlete training to participate in various championships both regionally and internationally [11].

The ability to work muscles or organs continuously over a period of time without experiencing excessive fatigue, in addition to endurance, endurance is one component of the physical condition that is highly needed in sports wrestling, for optimal athlete performance, recovery and body compositions, athletes need diet and synchronous physical activity [3].

Endurance endurance ability / endurance one can do by measuring VO2Max, understanding VO2Max is a body system that transports oxygen by the blood pumped from the lungs to muscle tissue [1]. $\mathrm{VO} 2 \mathrm{Max}$ is a measure to determine the endurance of one's Kardiorespiratori. VO2 Max is the level of oxygen consumption during exercise. the body's need for oxygen is determined by the intensity (weight) of movement or exercise performance [4].

\section{MATERIALS AND METHOD}

The method used in this study is the experimental method, Experiments are activities that are planned and executed by researchers to collect data related to the hypothesis. The researcher deliberately and systematically introduces the treatments into natural phenomena and then observes the consequences of the treatment. Data were collected through a 15 minute / balke test to see the aerobic endurance capability of the test performed during preliminary tests, intercultural tests, and final tests, then the data were analyzed to determine the improvement of aerobic endurance. Data analysis using SPSS Program with a significant level of 0.05 to prove whether the action is done on the athlete wrestling is an increase or not.

\section{RESULTS AND DISCUSSION}

The results showed that VO2 Max as a whole result from pretest $46,95 \%$, result of Cycle I test increased to equal to $49,43 \%$, and result of Cycle II test become more good again reach 50,21\%. VO2 Max results For More details can be seen in table 1 . 
TABLE I. DESCRIPTIVE STATISTICS DEPENDENT VARIABLE: VO2MAX

\begin{tabular}{|cc|c|c|c|}
\hline Test & STYLE & Mean & $\begin{array}{c}\text { Std. } \\
\text { Deviation }\end{array}$ & $\mathrm{N}$ \\
\hline Pretest & Gergo Roman & 49,6250 & 1,17333 & 4 \\
& FreeMan & 48,9225 & 1,99251 & 4 \\
& FreeWoman & 42,3175 & 5,28747 & 4 \\
& Total & 46,9550 & 4,57203 & 12 \\
\hline Test & Gergo Roman & 51,2875 & 1,45287 & 4 \\
SIklus I & FreeMan & 50,9725 & 2,45490 & 4 \\
& Free Women & 46,0250 & 1,92787 & 4 \\
& Total & 49,4283 & 3,09335 & 12 \\
\hline Test & Gergo Roman & 52,1075 & 1,31206 & 4 \\
Sik;lus 2 & Free Man & 51,8700 & 2,24643 & 4 \\
& Free Woman & 46,6575 & 2,07842 & 4 \\
& Total & 50,2117 & 3,15031 & 12 \\
\hline Total & Gergo Roman & 51,0067 & 1,60754 & 12 \\
& Free Man & 50,5883 & 2,40058 & 12 \\
& Free Woman & 45,0000 & 3,71675 & 12 \\
& Total & 48,8650 & 3,83112 & 36 \\
\hline
\end{tabular}

From the data above shows that the highest mean Vo2 Max is the Gergo Roman style exercise, which continues to increase from pretest, test result I and II test results, while the lowest is the women's freestyle exercise, To give a clearer picture can be seen in figure 1 .

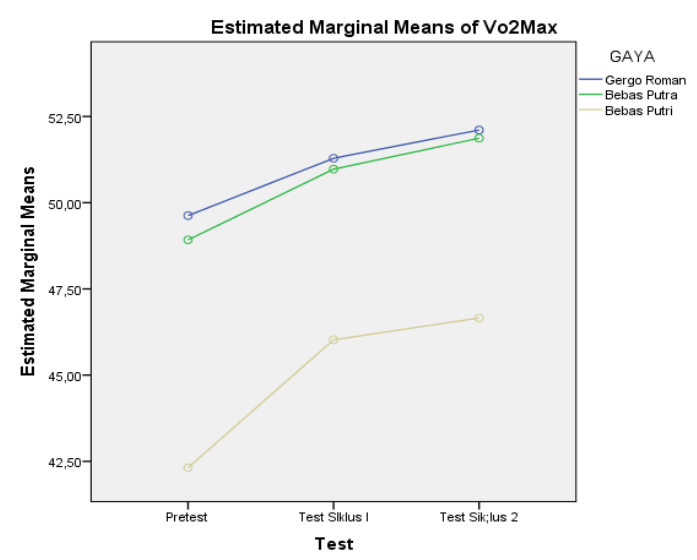

Fig 1. Hypothesis testing

From the calculation of variance analysis obtained summary as in the following table.

\section{TABLE II. TEST OF BETWEEN SUBJECT EFFECTS} DEPENDENT VARIABLE: VO2MAX

\begin{tabular}{|l|l|l|l|l|l|}
\hline Source & $\begin{array}{l}\text { Type III Sum of } \\
\text { Squares }\end{array}$ & $\begin{array}{l}\text { Mean } \\
\text { df }\end{array}$ & Square & F & Sig. \\
\hline $\begin{array}{l}\text { Corrected } \\
\text { Model }\end{array}$ & $344,973^{\mathrm{a}}$ & 8 & 43,122 & 6,900 &, 000 \\
Intercept & 85960,376 & 1 & 85960,376 & 13754,651 &, 000 \\
Test & 69,347 & 2 & 34,674 & 5,548 &, 010 \\
GAYA & 269,938 & 2 & 134,969 & 21,597 &, 000 \\
Test & 5,687 & 4 & 1,422 &, 228 &, 921 \\
GAYA & & & & & \\
Error & 168,738 & 27 & 6,250 & & \\
Total & 86474,087 & 36 & & & \\
Corrected & 513,711 & 35 & & & \\
Total & & & & & \\
\hline
\end{tabular}

a. $\mathrm{R}$ Squared $=, 672$ (Adjusted $\mathrm{R}$ Squared $=, 574$ )
From the table above can be explained things as follows.

a. The value of the Fcorrected model of 6,900 and its significance of 0,000 indicates that there are significant variations of Vo2Max by Test and exercise style at a significance level of 5\% (0.05).

b. The Ftest value of 5,548 and its significance of 0.010 indicates that there are significant variations of Vo2Max by Test (Pretest, Cycle I Test and Cycle II Test) and exercise style at 5\% significance level (0.05).

c. The Fgaya value of 21,597 and its significance of 0,000 indicates that there are significant variations of Vo2Max based on exercise style (Gergo Roman, Free Putra, and Free Princess) at a significance level of 5\% (0.05).

d. The FTest * style value of 0.228 and its significance of 0.921 indicates there is no significant Test and Style interaction in affecting Vo2Max. This means that the Test and Style each independently affect the variation of Vo2Max not interacting with each other.

The results showed the overall VO2 Max results from pretest $46.95 \%$, the results of the first cycle test increased to $49.43 \%$, and the results of the second cycle test to be better again reached $50.21 \%$. VO2 Max.

Seeing the results of the VO2 Max test above shows that the endurance of the wrestling athlete shows that the training interval endurance training methods and training programs provided to athletes are appropriate, that a high degree of aerobic ability is a prerequisite for enhancing performance [5].

\section{CONCLUSION}

The conclusion of this study is that endurance training (run interval) can increase VO2 Max Atlet Wrestling Indonesia, VO2 Max increase overall from, result of pretest $46,95 \%$, result of test of Cycle I increased to equal to $49,43 \%$, and the second cycle test results become more good again reached $50,21 \%$.

\section{REFERENCES}

[1] A. Elsam, Anusopati, "The influence of jogging training to VO2Max among low and normal haemoglobin groups of SMA Negeri 8 Bogor students", Journal SEGAR, Volume 3(2) pp. 80, 2015.

[2] Bompa T. O, "Total training for young champions", USA : Human Kinetik, 2000.

[3] D. Aerenhouts, E. Zinzen, and P. Clarys, "Energy expenditure and habitual physical activities in adolescent sprint athletes", Journal of Sports Science and Medicine 10, pp. 362, 2011.

[4] Friskawati, "The ability of VO2Max among freshies in physical education students of Pasundan Cimahi 2016/2017", Journal of Indonesia Physical education and Sport Vol 2(2), 2016.

[5] Y. Meckel, D. Bishop, M. Rabinovich, L. Kaufman, D. Nemet and A. Eliakim, "Repeated sprint ability in elite water polo player and swimmer and its relationship to aerobic and anerobic performance", Journal of sport science and medicine 12, pp. 738$743,2013$.

[6] Harsono, "Physical training", Bandung : FPOK UPI, 2001.

[7] Jesse E. Otero, C. M. Graves, and M. J. Bollier, Jurnal US National Library of Medicine National Institutes of Health, Volume 32, pp. 65, 2017. 
[8] Juhanis, "Dings skill waist in wrestling sport", Journal of Indonesia Physical Education and Sport Vol 2 (2), 2016.

[9] Mysidayu, Kurniawan, "Basic of coaching sciences", Bandung : Alfabeta, 2015.

[10] R. Hadi, "Basic of coaching sciences", Semarang: Rumah Indonesia, 2007.

[11] R. Hadi, "Defensive sports of gulat", Semarang: Fastindo, 2017.

[12] Sukadiyanto, "Theory and methodology of physical training", Yogyakarta : FIK UNY, 2005.

[13] Suhendro, "Main material of basic of coaching", Jakarta : UT, 2007.

[14] T. Juliantine, "Modul of training theory", Bandung : UPI, 2007. 